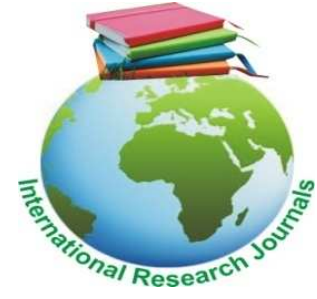

International Research Journal of Agricultural Science and Soil Science (ISSN: 2251-0044) Vol. 6(3) pp. 032-042, June, 2016

Avalable online http://www.interesjournals.org/lRJAS

DOI: http:/dx.doi.org/10.14303/irjas.2016.025

Copyright (C) 2016 International Research Journals

\title{
Effects of planting methods and tuber weights on growth and yield of yam cultivars (Dioscorea rotundata Poir.) in Gabon
}

\author{
Ondo Ovono Paul ${ }^{1 \star}$, Kevers Claire ${ }^{2}$, Dommes Jacques ${ }^{2}$ \\ ${ }^{1}$ Unit of Agrobiology Research, Higher National Institute of Agronomy and Biotechnology, Université des Sciences et \\ Techniques de Masuku, B.P. 941 Franceville (Gabon) \\ ${ }^{2}$ Plant Molecular Biology and Biotechnology Unit, B-22, University of Liège, SartTilman B 22, 4000 Liège, Belgium \\ *Corresponding author's E-mail:paulondo@hotmail.com
}

\begin{abstract}
A study was conducted to investigate the influence of planting methods and tuber weight on growth and yield of local yam cultivars obtained by the minisett technique from white yam (D. rotundata) in Gabon. Trials were carried out in 2014 and 2015 at the experimental ground of the Higher National Institute of Agronomy and Biotechnology, under natural conditions of lightness, temperature and relative humidity. Twenty- four weeks old mini tubers obtained from local cultivar MVA of $D$. rotundata were harvested, weighed and categorized $(40-80 \mathrm{~g} ; 100-150 \mathrm{~g} ; 200-300 \mathrm{~g}$ ), and three planting methods (horizontal, oblique and vertical), arranged in ridges constituted the main factors. The experiment was laid out in Randomized Completely Block Design with eighteen treatments and two replications. Data pertaining to sprouting were recorded for $30,60,90$ and $180 \mathrm{DAP}$, for tuber length (cm), tuber weight $(\mathrm{Kg})$ and number of tubers per plant 270 DAP. Significant differences among tuber weight in all variables tested were observed. The larger tubers had better sprouting ability than the rest of the tuber weight. The methods of planting had no effects on yield and its components but they affect the depth and spread of tubers. Vertical planting produced deeper but more compactly arranged tubers while horizontal planting produced tubers which were shallower but more widespread. Slanting was intermediate for both depth and spread. The number and weight of tubers obtained from mini tubers planted out according to slanting method were significantly different $(P<0.05)$ from other planting methods. The production of seedlings from mini tuber is an improvement of traditional production of seed yam. Mini tubers must have at least $100-300 \mathrm{~g}$ and they should be planted slanting or vertically.
\end{abstract}

Keywords: Dioscorea rotundata, yam, tuber weight, planting methods, sprouting, tuber production.

\section{INTRODUCTION}

Yams belong to family of Dioscoreaceae and are members of genus Dioscorea (Riley et al.,2006), which produces tubers and bulbils that are economically important in the zone of Benin, Cameroun, Côte d'Ivoire, Ghana, Nigeria and Togo (Agueguia, 2000; AdoukonouSagbadja et al., 2014). According to the same authors, yam occupies a significant place among the food crops produced in those zones where it represents at least 200 $\mathrm{cal} / \mathrm{j}$ in the food of 60 million inhabitants (Dibi et al., 2014). Yam tubers are important in different domains. Nutritionally, yam are a major source of food for millions of people (Craufurd et al., 2006) and secondly agriculturally, yams tubers are used as planting material and pharmaceutically, some species of Dioscorea, 
particularly Dioscorea zingiberensis, produces high concentration of diosgenin, a chemical used for the commercial synthesis of sex hormones and corticosteroids (Yuan et al, 2005).Thus, a considerable part of harvest is preserved as planting stock. According to Shiwachi et al. (2005), about 25 to $50 \%$ of the harvest of yams is used as such. Thus, the cost of the planting material increases the total production cost. This cost of planting material occupies more than $33 \%$ of the total cost of yam production (Dibi et al., 2014).The conventional multiplication of Dioscorea species is by tuber seeds, a tuber fragment that grows and develops into a new tuber. The traditional method of producing seed yams involves cuttings a seed yam into pieces called setts. Each sett weighs $100-300 \mathrm{~g}$ depending on location and tradition. Sett are then planted and seed yams weighing $200-1000$ grams are produced. However, quality seed yam is scarce. With this low multiplication ratio of $1: 4$, the number of seed yams produced is small. A seed yam production ratio (weight planted / weight harvested) ranging from 2.8 to 5.1 for cultivars of $D$.rotundata is normal. Other yam species except $D$. alata had even lower ratios. This low multiplication ratio in yam compares poorly with the grain crops. In maize (Zea mays) for instance a seed planted may produce 2 cobs each having up to 200 seeds: a multiplication ratio of 1 : 400. The need therefore existed for a method of rapidly multiplying yam planting materials. The minisett technique was developed to fill this need. In the modified minisett technique (Okoli and Akoroda, 1995; Ikeorgu and Igbokwe, 2003), use of $25-80 \mathrm{~g}$ minisett has reduced the production cost of seed yam (Oguntade et al., 2010) but rate of adoption is low.

The absence of viable seeds, the long period required for obtaining usable tubers and phytosanitary problems are some of the factors that limit the rapid conventional propagation and economic exploitation of Dioscorea species (Balogun et al., 2006; Tschannen et al.,2005). The yam tuber, which contains a deposit of starch, does not dormant buds as found on a typical tuber such as potato (Solanum tuberosum). However, at the end of dormancy a meristematic layer of cells beneath the skin of the tuber produces sprouts, usually from the head (proximal) region, indicating that the tuber is ready for planting. Most yam farmers use seed tubers saved from a previous crop for propagation. Due to short supply of quality seed tubers at affordable price, replacement of stocks of seed yams, which have been infested by pest and diseases, is usually not possible and farmers are forced to recycle poor quality seed yams with the risk of poor yields. Damage from nematodes, viruses, tuber rotting fungi and bacterial infections is a major contributor to the poor seed quality and low yields in yam.

Considering this large quantity of tubers engaged as seed that could have been available for human consumption, other modern methods of production of healthy seed yams were tested (Aighewi et al., 2015). More recently, rooting of $20 \mathrm{~cm}$ long 3-node vines (Acha et al., 2004; Kikuno et al., 2007; Shiwachi et al., 2005; Agele et al., 2010; Ayankanmi and Agele, 2010; Muamba et al., 2013; Dibi et al., 2014; Otoo et al., 2016);aeroponics system for seed yams production, (Behera et al., 2009; Sheeba et al., 2013; Maroya et al.,2014) produced mini tubers of 50 to $600 \mathrm{~g}$ after 8 months giving a 1: 22 propagation ratio;or the pregermination in seedbed (Asare-Bediako et al.,2007; Dasbak et al., 2011). All of these macro propagation techniques are genotype-dependent and have no provision for cleaning infected seed yam; tuber dormancy remains a challenge (Balogun et al., 2014).Tissue culture plays an important role in the production and international exchange of disease free planting materials of yams in form of plantlets and potentially as micro tubers, but it has some obvious limitations. These include high costs, the need for skilled personnel and specialized equipment, and more crop cycles are required to produce large quantities of suitable seed size tubers for ware yam production (Ondo Ovono et al., 2010; Balogun and Gueye 2013; Aighewi et al., 2015; Otoo et al., 2016). In Nigeria, the traditional yam planting techniques and materials were reported to be the same in different parts, although each region applied varies tillage types (Odjugo, 2008). Zero and manual tillage techniques are the commonest planting system among yam growers in Nigeria while ridge tillage techniques restricted to research stations (Ihebinike, 2009). Eborge (2002) reported that $100 \%$ of traditional yam farmers in Midwestern Nigeria used the slanting method in planting their yams, while none of respondents agreed to have used either the vertical or horizontal method. These methods he said are used for cassava planting. Kutugi (2002) and Obiokoro (2005) reported similar findings in the Middle belt and Western Nigeria respectively but both researchers used oblique method rather than slanting method. Seed yams and yam sett are the common planting materials in West Africa. Although Obiokoro (2005) reported significantly better emergence rate in seed yams, Akpoyovwire (2005) showed that the choice of planting materials that is available and affordable to them. In Ghana, cassava is propagated by stem cuttings $15-20 \mathrm{~cm}$ long, usually containing four to seven nodes. The cuttings are planted slanting at an angle to the soil surface, or sometimes vertically, with a third to a half of the cuttings buried; horizontally planting is very rare. The effect of method of planting on yield varies from country to country, and Krochmal (1969) attributed this to differences in the amount of rainfall. In some countries, completely burying the cuttings (horizontal planting) gave better yields than vertical or slant planting (Krochmal, 1969). In other countries, the opposite is the case. In 
034 Int. Res. J. Agric. Sci. Soil Sci.

Ghana and Nigeria the method of planting does not seem to affect yield (Gurnah, 1974).

The solutions are complex to improve the operating systems of the yams; they fall under the duration and aim at increasing the production and the output. The objectives of this study were to evaluate three planting mode and compare the response yam variety using the three categories of mini tuber under the ecological conditions of Masuku, in the South-east of Gabon. It must also make it possible to accumulate knowledge on the technological, agronomic and physiological aspects of the local varieties of cultivated yams.

\section{MATERIALS AND METHODS}

\section{Study area}

Over two years period, a study was conducted in the application research farm at the Higher National Institute of Agronomy and Biotechnology (INSAB), located in the administrative province of Haut-Ogooué, in the Southeast of Gabon on, natural conditions of lightness, temperature and relative humidity. The area of the study fits coarsely in a rectangle which co-ordinates are $13^{\circ}$ and $14^{\circ} 20$ East, and South $1^{\circ}$ and $1 \% 5$. It extends from the Congolese border in the East, on the Batékés plates, to the foot of the solid mass of Chaillu in the West, on approximately $6.960 \mathrm{~km}^{2}$. The altitude lies between 300 and $600 \mathrm{~m}$. The climate is equatorial of «transition» characterized by a great dry season (April-August) and a great rain season (September- November), followed by two small seasons: the small dry season (December February) and the small rain season (March - May). The presence of two dry seasons exerts an influence on the agricultural calendar, because they authorize two seasons of clearing and, thus two cycles of culture (Ondo Ovono et al., 2015). The annual average temperature is ${ }^{2} 4^{\circ} \mathrm{C}$. Annual average pluviometry varies between 1.700 and $2.200 \mathrm{~mm}$. Annual relative humidity is $81 \%$ and passes by two minima in August-September and in March-April (Guichard, 1977). The soil of Haut-Ogooué in general and Franceville in particular was the subject of many works: Azzibrouck (1986). The $\mathrm{pH}$ of the used zone varies between 4.5 and 5 and the content of clay is rather significant $(45-50 \%)$. The $\mathrm{pH}$ determination of the soil by the Analysis Laboratory of Soil of the INSAB, shows that the experimental site has an average potential acidity $(\mathrm{pH}$ water $=5.2$ and $\mathrm{pH} \mathrm{KCL}=4.7$ ). The vegetation is a secondary tropical forest having undergone several farming antecedents, in particular the culture of cassava with a prevalence of species such as: Hypparrheniadiplandra, Panicum maximum, Chromoleanaodorata, Puerariaphaseoloides and Schizochyriumplatyphyllum commonly considered as weeds.

\section{Preparation of planting material}

The yam material used was $D$. rotundata obtained from the modified minisett techniqe (Okoli and Akoroda, 1995). In the modified minisett technique, mother seed yam of $500-1000 \mathrm{~g}$ that have broken dormancy are cut into pieces weighed between $25-80 \mathrm{~g}$, according to the procedure described by Otoo et al., (1987); Kossou (1990); Kissiedu et al., (1994). The freshly cut minisetts are treated in a suspension containing the disinfectant (wood ash) and protectant (benomyl or benlate and aqueous neem leaf extract) and then spread out in light shade to dry for 1-2 days. Treated minisetts were presprouted in boxes measuring $50 \mathrm{~cm} \times 40 \mathrm{~cm}$ using saw dust as a medium. Each box contained 21 minisetts, comprising equal numbers of minisetts from head, middle and tail regions of the mother seed yam for MVA cultivar. Minisetts were laid out on a layer of moist heat sawdust in a box in such a way that their periderms touch the sawdust and spaced about $1 \mathrm{~cm}$ apart. They were then covered with another layer of moist heat sawdust. The boxes were watered as at when necessary. Formations of the mini tubers were observed 270 days after planting when the leaves senesced. Harvested tubers are stored under shade in an aired medium, the majority showing of the signs of breaking dormancy and they were selected according to three categories of weight (Figure 1A) (40$80 \mathrm{~g} ; 100-150 \mathrm{~g}$ and $200-300 \mathrm{~g}$ ). The choice of the tubers is done not only on the basis of their weight but also their good health state (Figure 1B).

\section{Preparation of treatment and planting}

The treatment comprised, yam cultivar MVA, one disinfecting, the wood ash (Sennaseamea) and a protectants (benlate or benomyl and aqueous neem leaf extract). Once the selected seed yams, using a bucket, we soaked them in $4 \mathrm{l}$ of solution (Asare- Bediako et al., $2007)$ containing disinfecting it $(120 \mathrm{~g}$ ashes of wood of Sennaseamea), and the protective agent (25g Benlate) (Figure 2A). A small basket of seed was plunged in the suspension during $3 \mathrm{~min}$. The treated seed yams are then spread out over sheets of palm leaves during $1 \mathrm{~h}$ for drying (Figure 2B). The land was newly cleared from secondary forest and prepared by to disc ploughings and harrowing followed by ridging. Yam mini tubers weighing (40-80g; 100-150g; 200-300g) were planted on ridges at $1 \mathrm{~m}$ spacing in each ridge and $1 \mathrm{~m}$ between the ridges. Planting took place on the $16^{\text {th }}$ July, 2014 and $8^{\text {th }}$ April, 2015 for the first and second planting season 

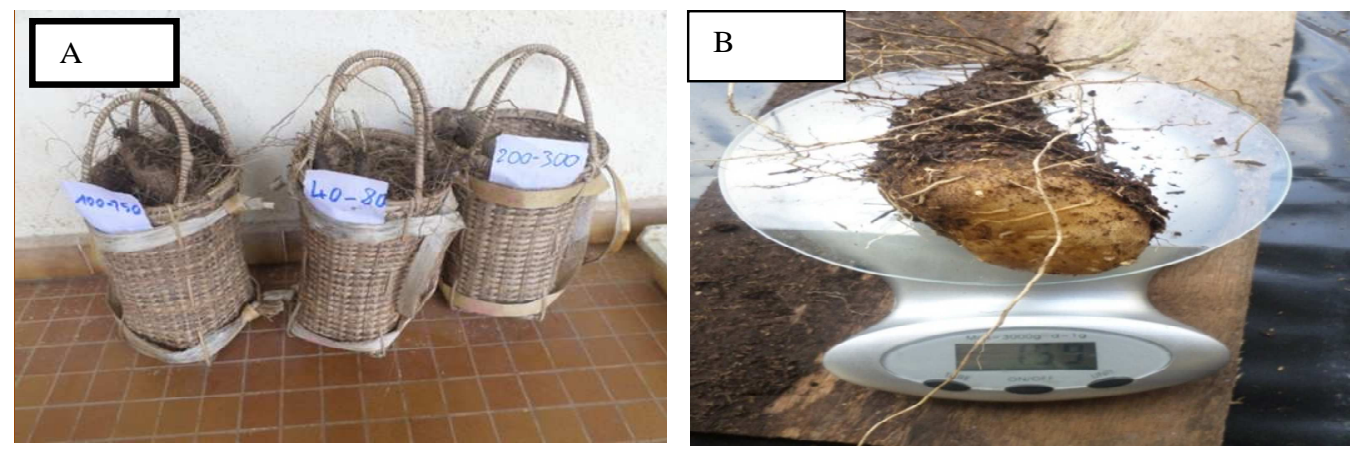

Figure 1: Categorization (A) and calibration (B) of tubers of yam
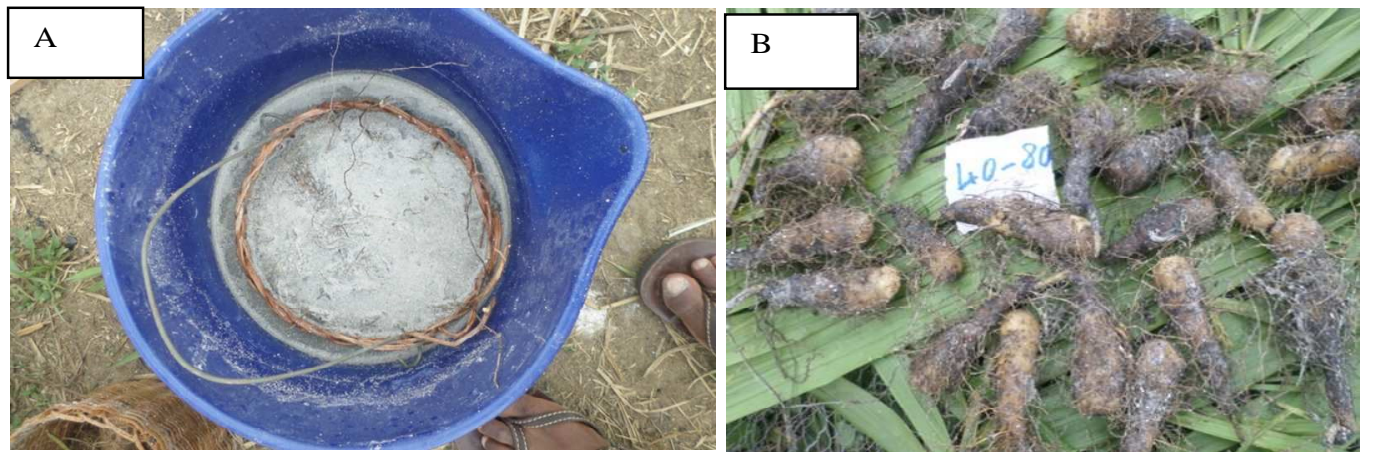

Figure 2: Steeping in a bucket $(A)$ and drying of the seeds on the sheets of palmer (B

respectively. Each plot contained three ridges, $4 \mathrm{~m}$ long. On each plot, 4 seed yams were planted, 12 in each replicate and in all 72 mini tubers of yam were planted. The useful surface area development is $12 \mathrm{~m} \times 6 \mathrm{~m}=72$ $\mathrm{m}^{2}$. The ridges are experimental units. They include four seed yams resulting from the tuber mother of white yam (D.rotundata); what gives a density of 10.000 seedlings to the hectare. Immediately after planting, mulching of appropriate plots followed. Non organic or inorganic fertilizer, nematicide, insecticide, fungicide or herbicide was applied. The culture on the ridges makes it possible to save space for other cultures, and to increase the density of plantation. Moreover, the ridges make it possible the plant to better benefit from rainwater selected. It is also more difficult with the rodents to cause damage with the tubers of average sizes.

\section{Experimental design and treatments}

The experiment was laid out in a $3 \times 3$ factorial design. This arrangement in split-plot design with two replications, is associated a device of randomized blocks comprising 18 experimental units. The planting methods evaluated were: Horizontal planting forming $180^{\circ}$ an gles with ridges; Incline planting forming $45^{\circ}$ to $60^{\circ}$ an gles with ridges; and vertical planting forming $90^{\circ}$ angl es with ridges. These planting methods were tested on three categories of mini tubers weighing $(40-80 \mathrm{~g} ; 100-150 \mathrm{~g}$; 200-300g). Thus, the mini tubers were planted according to the three modes. Each planting modes was carried out on two rides where there were 12 mini tubers per line (that corresponds to a double-line of 24 mini tubers). Three weeks later after the plantation, each plant was supported by an independent stake of bamboos to induce good canopy development. Weed control took place the 30 and the 60 days after plantation (DAP) by hand. The culture was watered every day if there was no rain.

\section{Data collection and statistical analysis}

Data were collected on the following parameters six months after planting, include emergence rate, which was counted 30, 60, 90 and 180 DAP (days after planting). The growth was measured weekly using the meter rule. Yam tuber yield parameters were measured at harvest. 
036 Int. Res. J. Agric. Sci. Soil Sci.

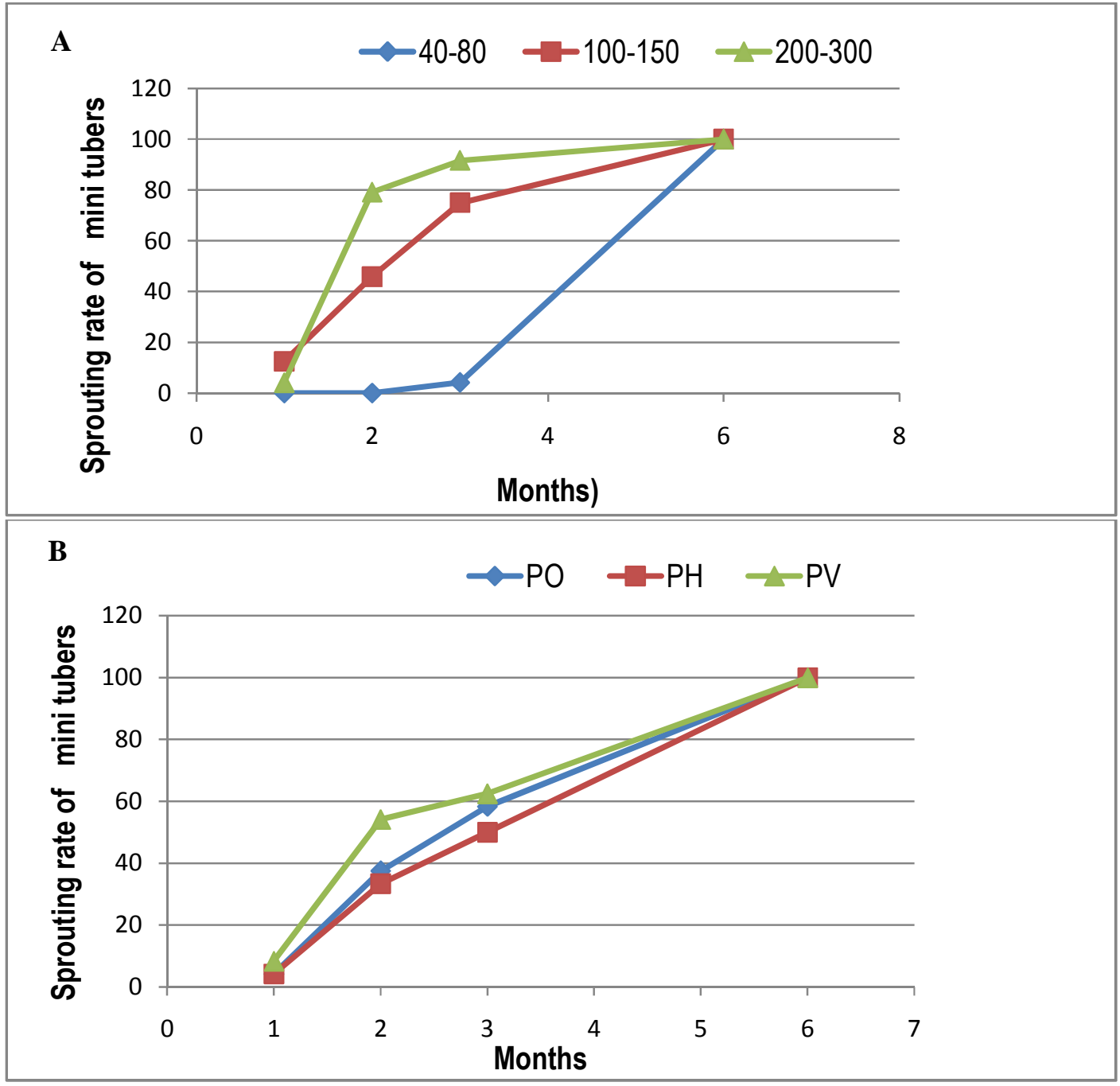

Figure 3: Evolution of sprouting yam mini-tubers according to categories $(A)$ and planting modes $(B)$ during 180 days.

Yam tuber weight was weighed using a weighing balance and yam tuber length with a measuring tape. For tuber length $(\mathrm{cm})$, tuber weight $(\mathrm{kg})$ and number of tubers per plant, parameters was measured 270 DAP. The number of tubers, the fresh weight of the tubers and the number of marketable tubers were determined by seedling at the maturity. Data collected were subject to the analysis of the variance (ANOVA) and treatment means were separated using Student-Newman-Keuls Test when the difference between the averages was significant with the threshold of $5 \%$.

\section{RESULTS}

\section{Emergence rate}

The observations carried out during two planting seasons, 2014/2015 and 2015/2016 indicate a very heterogeneous sprouting of the seed yams used according to the category and the planting mode. In general, sprouting is spread out in time. The percentage emergence was observed 30,60, 90 and 180 days after the plantation. One notices (Figure $3 \mathrm{~A}$ ) a late starting of the seed after their setting in culture but at 180 days, all the types of seed sprouted. Sprouting passed from $0 \%$ at 60 days to $100 \%$ at 180 days for the category $40-80 \mathrm{~g}$ (Figure 3A). Results show the different mini tubers may have different sprouting abilities. Planting mode of the seed has significant effects neither on the average number of days with $50 \%$ of emergence nor on the average number of definitively established seedlings ( $p=$ 0.05) (Figure 3B). At days 180, the percentage of sprouting of the seed is maximal whatever the planting mode (Figure 3B). More than one principal stem was observed on average after emergence of the seed of the 
Table1: Effects of planting modes and weights of yam mini tubers on the diameter $(\mathrm{cm})$ of the seedling collect six months after planting.

\begin{tabular}{lcccc}
\hline \multirow{2}{*}{ Planting modes } & \multicolumn{4}{c}{ Categories of seed yam } \\
\cline { 2 - 5 } & $40-80 \mathrm{~g}$ & $100-150 \mathrm{~g}$ & $200-300 \mathrm{~g}$ & Average \\
horizontal & $1.8 \pm .3$ & $2.1 \pm 0.6$ & $2.7 \pm 0.7$ & $2.2 \pm 0.8^{\mathrm{a}}$ \\
oblique & $1.7 \pm 5.1$ & $2.0 \pm 0.4$ & $2.1 \pm 5.2$ & $1.9 \pm 1.2^{\mathrm{ab}}$ \\
vertical & $2.1 \pm 2.7$ & $2,1 \pm 0.3$ & $2.7 \pm 2.7$ & $2.3 \pm 1.3^{\mathrm{a}}$ \\
Average & $1.9 \pm 2.0^{\mathrm{a}}$ & $2.0 \pm 1.4^{\mathrm{ab}}$ & $2.5 \pm 0.4^{\mathrm{b}}$ & \\
\hline
\end{tabular}

The average numbers followed by identical letters are broadly equivalent to the probability threshold $p<0.05$

Table 2: Effects of planting modes and weights of yam mini tubers on the height $(\mathrm{cm})$ of the first branch on the ground of the seedlings six months after planting.

\begin{tabular}{lcccc}
\hline & \multicolumn{4}{c}{ Categories of seed yam } \\
\cline { 2 - 5 } Planting modes & $40-80 \mathrm{~g}$ & $100-150 \mathrm{~g}$ & $200-300 \mathrm{~g}$ & Average \\
horizontal & $23 \pm 4$ & $39 \pm 4$ & $49 \pm 3$ & $37 \pm 4^{\mathrm{b}}$ \\
oblique & $28 \pm 2$ & $39 \pm 1$ & $50 \pm 2$ & $39 \pm 2^{\mathrm{b}}$ \\
vertical & $24 \pm 2$ & $33 \pm 6$ & $48 \pm 8$ & $35 \pm 5^{\mathrm{a}}$ \\
Average & $25 \pm 4^{\mathrm{a}}$ & $37 \pm 4^{\mathrm{b}}$ & $49 \pm 9^{\mathrm{b}}$ & \\
\hline
\end{tabular}

The average numbers followed by identical letters are broadly equivalent to the probability threshold $p<0.05$.

Table 3: Effects of planting modes and weight of yam mini tubers on the average weight $(\mathrm{kg})$ of the tubers produced nine months after planting.

\begin{tabular}{lccccc}
\hline & \multicolumn{3}{c}{ Categories of seed yam } & \multicolumn{2}{c}{ Average } \\
\cline { 2 - 6 } Planting modes & $\mathbf{4 0 - 8 0 g}$ & $\mathbf{1 0 0 - 1 5 0 g}$ & $\mathbf{2 0 0 - 3 0 0 g}$ & $\begin{array}{c}\text { Tuber Weight } \\
\mathbf{( k g / s t a n d )}\end{array}$ & $\begin{array}{c}\text { Tuber Yield } \\
\mathbf{t} / \mathbf{h a})\end{array}$ \\
Horizontal & & & $5.450 \pm 0.005^{\mathrm{a}}$ & $34.50^{\mathrm{a}}$ \\
Oblique & $2.675 \pm 0.008$ & $2.300 \pm 0.011$ & $5.375 \pm 0.004$ & $3.700 \pm 0.004^{\mathrm{a}}$ & $47.00^{\mathrm{a}}$ \\
Vertical & $4.300 \pm 0.008$ & $3.275 \pm 0.003$ & $6.525 \pm 0.008$ & $4.166 \pm 0.004^{\mathrm{a}}$ & $41.66^{\mathrm{a}}$ \\
Average & $4.125 \pm 0.008$ & $3.225 \pm 0.009$ & $5.150 \pm 0.009$ & \\
Tuber Yield (t/ha) & $3.700 \pm 0.007^{\mathrm{b}}$ & $2.933 \pm 0.005^{\mathrm{a}}$ & $5.683 \pm 0.008^{\mathrm{c}}$ & & \\
\hline
\end{tabular}

The average numbers followed by identical letters are broadly equivalent to the probability threshold $p<0.05$

categories of weight $100-150 \mathrm{~g}$ and $200-300 \mathrm{~g}$, but no variation due to the planting mode (obliquely, horizontal and vertical) is observed 6 months after the setting in culture (data non shown).

\section{Growth and development of the seedlings after six months}

The average stem diameter of the principal stem in relation to the weight of the seed is classified in the order $200-300 \mathrm{~g}=100-150 \mathrm{~g}>40-80 \mathrm{~g}(\mathrm{p}<0.05)$. In other hand, more the weight of the seed is high, more significant is the diameter with the collect of the seedling which results from it (Table 1). As for the average height of the first branch from the ground (Table 2), it was respectively higher for the seed of the categories, $40-80$ $\mathrm{g}, 100-150 \mathrm{~g}$ and $200-300 \mathrm{~g}$ of $25 \mathrm{~cm}, 37.2 \mathrm{~cm}$ and $48.7 \mathrm{~cm}$ after 6 months of culture.

\section{Growth and development of the seedlings after nine months}

At maturity (Tables 3, 4 and 5), the size, the fresh weight and the average number of tubers collected by seedling were noted for each method of planting and the category of tubers. The method of planting affected the depth of tubers, the number of stems and lodging percentage. The vertically planted mini tubers produced tubers which were 
038 Int. Res. J. Agric. Sci. Soil Sci.

Table 4: Effects of planting mode and weights of yam mini tubers on the average length of tubers $(\mathrm{cm})$ produced nine months after planting.

\begin{tabular}{lcccc}
\hline & \multicolumn{3}{c}{ Categories of seed yam } & \\
\cline { 2 - 4 } Planting modes & $\mathbf{4 0 - 8 0 ~} \mathbf{~ g}$ & $\mathbf{1 0 0 - 1 5 0 ~ g}$ & $\mathbf{2 0 0 - 3 0 0 ~} \mathbf{~}$ & Average \\
\hline Horizontal & $42.7 \pm 3.5$ & $35.5 \pm 4.3$ & $48.0 \pm 5.3$ & $42.1 \pm 0.5^{\mathrm{a}}$ \\
Oblique & $46.1 \pm 3.0$ & $46.0 \pm 3.5$ & $51.0 \pm 4.9$ & $47.7 \pm 0.5^{\mathrm{a}}$ \\
Vertical & $49.7 \pm 5.9$ & $41.0 \pm 4.4$ & $54.7 \pm 4.4$ & $48.5 \pm 0.5^{\mathrm{a}}$ \\
Average & $46.2 \pm 3.0^{\mathrm{b}}$ & $40.5 \pm 3.5^{\mathrm{a}}$ & $51.2 \pm 0.5^{\mathrm{c}}$ & \\
\hline
\end{tabular}

The average numbers followed by identical letters are broadly equivalent to the probability threshold $p<0.05$

Table 5: Effects of planting modes and weights of yam mini tubers on the average number of tubers produced nine months after planting.

\begin{tabular}{lcccc}
\hline \multirow{2}{*}{ Planting modes } & \multicolumn{3}{c}{ Categories of seed yam } & \\
\cline { 2 - 4 } & $\mathbf{4 0 - 8 0 \mathbf { g }}$ & $\mathbf{1 0 0 - 1 5 0 g}$ & $\mathbf{2 0 0 - 3 0 0 g}$ & Average \\
\hline Horizontal & $4.7 \pm 0.8$ & $3.6 \pm 0.7$ & $5.7 \pm 0.6$ & $4.7 \pm 0.6^{\mathrm{b}}$ \\
Oblique & $6.3 \pm 1.0$ & $4.0 \pm 0.7$ & $5.5 \pm 0.4$ & $5.2 \pm 0.4^{\mathrm{b}}$ \\
Vertical & $2.7 \pm 1.3$ & $3.5 \pm 2.7$ & $1.5 \pm 0.3$ & $2.5 \pm 0.3^{\mathrm{a}}$ \\
Average & $4.6 \pm 1.1^{\mathrm{b}}$ & $3.7 \pm 3.9^{\mathrm{a}}$ & $4.3 \pm 0.2^{\mathrm{b}}$ & \\
\hline
\end{tabular}

The average numbers followed by identical letters are broadly equivalent to the probability threshold $\mathrm{p}<0.05$

about $10 \mathrm{~cm}$ deeper but more compactly packed around the stem than horizontally planted ones. Tubers from horizontally planted mini tubers were slightly shallower, as already seen, but their horizontal spread was about 20 $\mathrm{cm}$ wider than that of vertically planted mini tubers. Mini tubers planted in the slanting method were intermediate between the horizontal and vertical plantings in terms of depth and spread of tubers. Yam tuber yield parameters were better enhanced in manually ridged in the study.

The average weight of the tubers varies from $3.45 \mathrm{~kg}$ to $4.70 \mathrm{~kg}$ respectively for the horizontally and the obliquely method of planting. The statistical analysis does not reveal any significant difference between weights of tubers resulting of different planting methods. The average length of the tuber (Table 4) passed from 42.1 $\mathrm{cm}$ for the horizontal position to $48.5 \mathrm{~cm}$ for the vertical method without it having a significant difference between the slanting method and the vertical method $(p<$ 0.05). Being the number of produced tubers (Table 5), only the obliquely and the horizontally planted seed gave a significant number of tubers per seedling (5.2 and 4.7 respectively) different from the vertical position (2.5). The slanting method of planting recorded highest mean number of tubers per plant (5.2). It was statistically higher than the mean number of tubers (2.5) produced by the mini tubers planted according to the vertical method of planting. Planting methods (obliquely) were however statistically identical to the horizontal method of planting
(4.7). The best mean weight of tubers was obtained from slanting method of planting $(4.7 \mathrm{~kg})$, being no significant difference was noted between the two other planting methods (Table 3 ).

The mean numbers, length and weight of tubers per plant obtained from categories were significantly different $(p<0.05)$.As for the planting mode, the average weight of tubers produced varies from $2.93 \mathrm{~kg}$ for the category $(100-150 \mathrm{~g})$ to $5.68 \mathrm{~kg}$ for the category $(200-300 \mathrm{~g})$. With regard to the category, the statistical analysis reveals significant differences $(p<0.05)$. In the order descending of the categories of weight studied, the average weights of the produced tubers are $5.68 ; 2.93$ and $3.70 \mathrm{~kg}$ respectively (Table 3 ). On the other hand, the number of tubers produces for category differs significantly, lower for the category 100-150 (Table 5). The means length and weights were also significantly lower for this category $(100-150 \mathrm{~g})$. Highest mean number, length and weight were obtained from the categories $(40-80$ and 200$300 \mathrm{~g})$. On the contrary the category $(100-150 \mathrm{~g})$ produced lowest number and weight (3.7 and $2.93 \mathrm{~kg}$ respectively) of tuber. There was no significant difference between the categories $(40-80 \mathrm{~g})$ and $200-300 \mathrm{~g})$ in term of number of tubers. However a mean weight obtained from the category $(200-300 \mathrm{~g}) 5.7 \mathrm{~kg}$ was statistically higher than the one produced by $40-80 \mathrm{~g}(3.7 \mathrm{~kg})$.

The average number of marketable tubers that is those having a cylindrical form, a weight ranging between 
500 and $900 \mathrm{~g}$ and not having any defect varies to a significant degree according to positions' of the seed at the time of the plantation or according to categories' of weight to which they belonged $(p=0,05)$. It corresponds to $40 \%$ of the collected tubers, generated by the categories $100-150 \mathrm{~g}$ and $200-300 \mathrm{~g}$ against $29 \%$ counted with the seeds yam of $40-80 \mathrm{~g}$. The oblique and vertical methods contributed to the respective production of $27 \%$ and $47 \%$ of marketable tubers. The interaction between categories and planting mode was not significant $(p=$ 0.64 ) for the all parameters of tubers per plant.

\section{DISCUSSION}

The production of this crop like every other crop is affected by factors varying from physical, economic to cultural (Obiokoro, 2005). Climate, one of the physical factors, is the most crucial factor, which determines the nature of the natural vegetation, the characteristics of the soils, the crops that can be grown, and the type of farming that can be practiced in any region (Obiokoro, 2005). The most important climatic elements for crop growth and yield are radiant energy, or solar radiation, temperature and water or rainfall (Ekaputa, 2004). Soil and air temperatures affect the developmental stages more than any other factor (Ayoade, 2002). Of the two, soil temperature is a better indicator of energy condition required for crop development and yield than air temperature. When soil is tilled, total porosity is increased, this enhance vapor movement by diffusion and mass flow of air, result in an increase in moisture evaporation. The fragmentation of the soil structure caused by tillage might have led to the creation of more macropores which in turn, made the soil more porous and more susceptible to deep percolation and this would enable the soil to contain moderate water in good proportion needed by the plant and at the same time create room for air space for good aeration which is essential for proper plant growth (Ohiri and Ezumah, 1990).

The range of soil temperature obtained in the study fall within the optimum temperature range of $2^{\circ} \mathrm{C}-35^{\circ} \mathrm{C}$ required for good yam growth and yield. This observation was in agreement with the report of Adekayode, (2002), Passam, (1977) examined the effects of temperature at saturating relative humidity on $D$. alata. He observed sprouting to occur after $20 \mathrm{~d}$ at 25 and $30{ }^{\circ} \mathrm{C}$, and 30 to $40 \mathrm{~d}$ at $17{ }^{\circ} \mathrm{C}$. Many other studies have also shown $\mathrm{cool}$ temperatures between 16 and $20^{\circ} \mathrm{C}$ delay sprouting (Passam, 1977). In contrast, Rivera et al. (1974a) observed that at $16-18{ }^{\circ} \mathrm{C}$ sprouting occurred earlier at $70 \%$ than at $80 \%$ relative humidity. Temperature and relative humidity are the major determinants of evaporation rate and hence water-loss (Craufurd et al.
2001).

To use yam mini tubers as seeds, it is important to be sure that all the tubers are able of sprouting. Meanwhile, mini tubers must be stored. But, as for traditional tuber cultures, mini tubers could present a dormant period. The mechanism of dormancy in yam, and for that matter in other tuberous species too is poorly understood and so the physiological dormancy period cannot be easily predicted or manipulated (Orkwor and Ekanayake, 1998). In this study it was observed that mini tubers harvested after 9 months and cultivated in the fields, following three planting methods of planting: horizontal, slanting and vertical, and three categories of mini tubers: $40-80 \mathrm{~g}$; 100-150 g; $200-300 \mathrm{~g}$ survived, developed new stems and formed tubers. Alsadon et al. (1988) have shown that larger micro tubers of potato were able to produce a larger crop than small ones when they were transplanted or directly sown into the field. In yam, the effect of tubers size was also very important for the further sprouting. The sprouting of large mini tubers $(100-150 \mathrm{~g}$ and $200-300 \mathrm{~g})$ occurred earlier than that of the smaller tuber $(40-80 \mathrm{~g})$ sprouted.

However sprouting ability varied with stage of physiological maturity and size (Balogun, 2009). Quality of seed depends on the starch content which is related to sprouting vigor (Park et al., 2001). Bigger mini tubers had more reserves and thus could more easily sprout although the dormant period was generally associated with a minimum of endogenous metabolic activity, resulting in very little loss of storage reserve. These results also confirmed those of (Vakis, 1986) who showed that more field tubers were physiologically large more the seeding was fast. Then, by aging, their germinal vigor is increased and, consequently, the seeding was accelerated. Variability in the duration of dormancy has been attributed to differences in species, variety crop management, data of tuber harvest, growth, and storage (Hamadina and Asiedu, 2015). Long dormancy of tubers is a desirable attribute in yam breeding and selection programs (Shiwachi et al. 2003). It permits a better storage but it complicates the use of the tuber for propagation. For in vitro culture, when micro tubers where harvested and directly transferred on a new medium without hormones, the tubers rapidly sprouted. After one week, around $50 \%$ of the tubers have sprouted and after 8 weeks, all the tubers have sprouted (Ondo Ovono et al. 2010). However, sprouting ability varied with stage of physiological maturity and size (Balogun, 2009). In traditional culture, dormancy is widely assumed to start at or shortly after tuber maturity and most studies begin measuring dormancy time from harvest.

However, various studies showed that in fact field tuber are dormant well before harvest (Wickham et al. 1984, Craufurd et al. 2001). Indeed, we obtained the first signs of dormancy breaking after 30 days for the 
040 Int. Res. J. Agric. Sci. Soil Sci.

categories (100 - $150 \mathrm{~g}$ and $200-300 \mathrm{~g})$. The observations relating to the effects of the categories of seed on the production of the tubers are in agreement with those of Behera et al. (2009) and Muamba et al. (2013) according to which the largest seed would be able to contribute to the development of new tubers by the direct transfer of reserves in nutritive elements to these tubers under development.

The mean number of tuber per plant obtained from D.rotundata was 3.7 and 4.6 , and weighed respectively 2.9 and $5.7 \mathrm{~kg}$ for categories $100-150 \mathrm{~g}$ and $200-300 \mathrm{~g}$. Nevertheless, the result obtained was higher than those reported by Kossou (1990) showing that D.rotundata produced $313,5 \mathrm{~g}, \quad 782,5 \mathrm{~g}$ and $992,8 \mathrm{~g}$ tubers respectively for the categories $(40-80 \mathrm{~g} ; 100-150 \mathrm{~g}$ and $200-300 \mathrm{~g}$ ). The difference with our results was probably due to the time of harvesting (9 months) and the prevailing temperature $\left(27^{\circ} \mathrm{C}\right.$ on average) during the propagation. In the other hand it seems that D.rotundata performs better in our environment. This might be due the fact that manually tilled plots had lower bulk density and higher total porosity which might have improved root penetration and tuber induction in the soil. In support of this, Ohiri and Nwokoye (1984) indicated that yam requires a loose, deep soil to allow permeability of air and water to tubers. That might explain the larger cultivation of that species in Gabon. Elsewhere, these yams do not produce tubers (Ondo Ovono et al. 2015).

The methods of planting had no effects on yield and its components but they affected the depth and spread of tubers. Slanting planting method associated with the various categories of the seed led to a greater number of tubers to larger harvest and, but the vertical and the horizontal planting seem to support a prevalence of the cylindrical forms, which is a good indicator for the production of seed. The differences in the depth and spread of tubers would be very important if yam harvesting is mechanized. The wide spread of the horizontal tubers would be a great disadvantage since the tubers are more likely to be broken. Although the number of tubers harvested per plot counts in yield evaluation, the best parameter as earlier noted is the weight of the tubers since it is directly related to the weight of the tuber and the cost of any yam tuber is determined more by its size length and weight (Eborge, 2002; Oamen, 2004; Adeleye et al. 2011).Seed yams should be harvested carefully to minimize cuts and wounds. Harvested tubers should be stored in airy, well shaded or covered barns. Although they may be stored for up to 4 months, seed yams are best planted within 3 months of harvestings them. However for tuber yield, the best practice as revealed by this study is planting the yam using ridge tillage following by slanting modes (47t/ha) and tuber weight (200-300 g) (56t/ha). This gives a mean yield of $51.5 \mathrm{t} / \mathrm{ha}$. The yield of the best treatment in this study is higher than the common traditional practice (12t/ha). These results can be used for optimizing mass production of mini tubers in yam and especially in $D$. rotundata. They especially showed the importance of tuber production conditions on tuber length and weight and on their further sprouting.

\section{CONCLUSION}

The use of different planting modes of yam mini tubers has an impact on tubers production. The local variety MVA and the planting modes have a good effect on the propagation using mini tubers. The results obtained confirm the possibility to produce tubers from mini tubers, which tubers can be used in field as planting material in order to produce consumable yams. Tubers obtained on the bigger categories sprouted rapidly than the smaller and after 180 days all the tubers had sprouted. The categories of tubers had effect on yield and other parameters tested. The methods of planting had no effects on yield, and its components, but they affected the depth and spread of tubers. Vertical planting produced deeper but more compactly arranged tubers while horizontal planting produced tubers which were shallower but more widespread. Slanting was intermediate for both depth and spread.

For mechanical harvesting, vertical planting is the best; but for hand harvesting any method of planting can be used, although planting vertical or slanting gives plants less prone to lodging. For ware yam tubers production, the best practice, which can be recommended to yam farmers in the humid tropics, is for them to plant their yam using ridges tillage with larger tuber. The mini tubers must have at least $100-300 \mathrm{~g}$ and they should be planted slanting or vertically. Seed yams should be harvested carefully to minimize cuts and wounds. Harvested tubers should be stored in airy, well shaded or covered barns. Although they may be stored for up to 4 months, seed yams are best planted within 3 months of harvestings them. This study has taken into account only agronomic parameters. So, in futures studies, it would be interesting to asses not only the production cost of the seeds which can sow one hectare, but also to stand out the socio-economic impact on Gabon population.

\section{ACKNOWLEDGEMENT}

The author thanks the President for the Departmental Council of M'PASSA for allowing us to carry out the experimentations and to have provided technical supports and materials of plantation, INSAB for the good collaboration. 


\section{REFERENCES}

Acha IA, Shiwachi H, Asiedu R, Akoroda MO (2004). Effect of auxins on root development in yam (Dioscorea rotundata) vine. Trop. Sc. 44, 80-84.

Adekayode FO (2002). Effects of tillage practices on soil properties and yield of seed yam in southwest Nigeria. Agric. Sci. J.,1: 14-21.

Adeleye EO, Ayeni LS, Ojeniyi SO (2011). Effect of tillage techniques on soil properties Nutrient uptake and yield of yam (Dioscorea rotundata) on an Alfisol in South western Nigeriar. J. Agric. Food. Tech. 1(6) 94-100.

Adoukonou-Sagbadja $H$, Missihoun AA, Sedah $P$, Dagba RA, Kinhoegbe G, Ahanhanzo C, Agbangla C (2014). Variabilité génétique des accessions d'igname Dioscorea alata $\mathrm{L}$. introduites au Bénin à partir des lles du Sud-Pacifique. J. Appl. Biosci. 73 : 5966-5978

Agele SO, Ayankanmi TG, Kikuno H (2010). Effects of synthetic hormone substitutes and genotypes on rooting and mini tuber production of vines cuttings obtained from white yam (Dioscorea rotundata, Poir.).African J.Biotech. 9: 4714-4724.

Agueguia A (2000). Importance and uses of coco yam in Cameroonian diets, in: Nakatani and Komati (editors). $20^{\text {th }}$ symposium of the International Society for Tropical Root Crops (ISTRC). IPGRlion Session. TsukubaJapan, pp: 512-514.

Aighewi BA, Asiedu R, Maroya N, Balogun M (2015). Improved propagation methods to raise the productivity of yam (Dioscorea rotundata Poir.). Food Sec. 7: 823-834.

Akpoyovwire AS (2005).Effect of terrain and culture on the choice of tillage types and production of root in Nigeria. J. Agric. Ext. 4(1): 6585.

Alsadon AA, Knutson KW, Wilkinson JC (1988). Relationships between micro tuber and mini tuber production and yield characters of six potato cultivars. Am. Potato. J. 65: 468

Asare-Bediako E, Showemimo FA, Opoku-Asiama Y, Amewowor DHAK (2007). Improving sprouting ability of white yam minisett (Dioscorea alata Poir.) varpona and dente using different disinfectants and protectant in sterilized saw dust. J. Applied Sci. 7: 3131-3134.

Ayankanmi TG, Agele SO (2010).Effect of Genotype, Root-Promoting Substances and Planting Media on Yam (Dioscorea rotundata, Poir.) Vine Cutting for Mini Tuber Production. Adv. Environ. Biol. 4: 353-359.

Ayoade JC (2002). Agroclimatology. Ibadan: Advatae Publishers. P. 129-137.

Azzibrouck AG (1986). Sédimentologie et géochimie du Francevillien B ( protérozoiqe inférieur). Métallogénie des gisements de manganese de Moanda Gabon. Thèse université ULP. Strasbourg. 210p.

Balogun MO, Fawole I, Ng SYC, Ng NQ, Shiwachi H, Kikuno HG (2006). Interaction among cultural factors in microtuberization of white yam (Dioscorea rotundata Poir.). Trop. Sci. 46 (1): 55 -59.

Balogun MO (2009). Micro tubers in yams germ plasm conservation and propagation: The status, the prospects and the constraints. Biotechnol. Mol.Biol. Rev. 4(1): 1-10.

Balogun MO, Gueye B (2013). Status and prospectus of biotechnology applications to conservation, propagation and genetic improvement of yam. In K.G. Ramawatand J-M Merillon (Eds.), Bulbous Plants: Biotechnology (pp. 92-112). CRS Press.

Balogun MO, Maroya N, Asiedu R (2014). Status and prospects for improving yam seed systems using temporary immersion bioreactors African J.Biotechn. 13: 1614-1622.

Behera KK, Pani D, Sahoo S, Maharana T, Sethi BK (2009). Effect of $\mathrm{GA}_{3}$ and Urea treatments on Improvement of micro tuber production and productivity of different types of planting material in greater yam (Dioscorea alata L.). Not. Bot. Hort. Agrobot. Cluj 37: 81-84.

Craufurd PQ, Summerfield RJ, Asiedu R, Vara Prasad PV (2001). Dormancy in Yams. (Dioscorea spp.). Exp. Agr. 37: 75-119.

Craufurd PQ, Battey NH, Ile El, Assiedu R (2006). Phase of dormancy in yams tubers. (Dioscorea rotundata). Ann. Bot. 97: 497-504.

Dasbak MA, Manggoel W, Dawang CN (2011). Evaluation of nursery sprouting media for the minisetts of some Dioscorea rotundata yam cultivars and the field establishment of sprouted minisetts in Garkawa, Plateau State, Nigeria. Int. Res. J. Agric. Sci. Soil Sci. 1 : 481 - 484

Dibi K, Kouakou AM, Yéo JT, Fofana I, N'Zue B, Brou YC (2014). Effects of planting modes on yam (Dioscorea alata L.) vine cutting for mini tubers production. Intern. J. Sci. 3:1-8.

Eborge EOD (2002). Comparative analysis of the growth and yield of yams under mound and ridge taillage. J.Agric. Dev. $6: 54-66$.

Ekaputa UN (2004). Agricultural systems. Port Harcourt: UNIK Publishers.pp.126-134.

Guichard $E(1977)$. Etude pédologique de la bergerie de Franceville: ORSTOM, centre de Libreville 105 pp. multigr.

Gurnah AM (1974). Effects of method of planting and the length and types of cuttings on yield and some components of cassava (ManihotesculentaCrantz) grown in the forest zone of Ghana. Ghana J. agric. Sci. 7. 103-108.

Hamadina El, Asiedu R (2015). Effect of Provenance and Storage Agroecology on Duration of Yam (Dioscorea rotundata Poir.) Tuber Dormancy, Forestery and Fisheries. 4: 95-100.

Ihebinike CRN (2009). The impact of traditional tillage types and practices on the yield of white yam, yellow yam and water yams in eastern Nigeria. Agric.Rev. 1: 44-52.

Ikeorgu JEG, Igbokwe MC (2003). Seed yam production with minitubers. Niger Agric. J. 34 : 63-67.

Kikuno H, Matsumoto R, Shiwachi H, Youohara H, Asiedu R (2007). Comparative effects of explant sources and age of plant on rooting, shooting and tuber formation of Vine cutting of yams. Japanese J. Trop. Agric. 51: 71-72.

Kissiedu AFK, Okoli OO, Asare- Bediako M, Lamptey JNL, Danso AK (1994). Ghana root and tuber crops research. In M.O. Akoroda (Ed.), Root crops for food security in Africa (pp. 435-440). Kampala: Proc $5^{\text {th }}$ TriennalSymp. of ISTRC-AB.

Kossou DK (1990). Evaluation de pratiques culturales relatives à la production de semenceaux et tubercules d'ignames (Dioscorea rotundata) au Bénin. Tropicultura8 : 69-73.

Krochmal A (1969). Propagation of cassava Wld crops 21:193-195.

Kutugi AD (2002). Comparative analysis between indigenous and modern tillage pratices in the production of Dioscorearotundata and Dioscoreacayenes is in the Midle Belt of Nieria. J. .Agric. Environ. 2: 53-66.

Maroya N, Balogun M, Asiedu R (2014). Seed Yam production in aeroponics system : a novel technology. YIIFSWA Working Paper No 2. Institute Intl. Tropical Agric. Ibadan, Nigeria.9p.

Muamba JK, Uzoma CK, Berhanu DB, Kikuno H (2013). Vine cuttings technology in food yam (Dioscorea rotundata) production. Asian J. Plant Sci. Res. 3: 107- 111.

Oamen DE (2004). The influence of Tillage tpes on the types on the yield of intercropped melon and Yam. Agro. Dev. Environ. Protec. Monograph.8: 5-8.

Obiokoro OG (2005). Agrometeorology. Onitsha: Dunkwu Publishers. Pp.24-30.

Odjugo PAO (2008). The effect of taillage systems and mulching on soil microclimate, growth and yield of yellow yam (Dioscorea cayenensis) in Mid western Nigeria. Afric. J.Biotechn.F 7 (24): 4500 4507.

Oguntade A, Thompson OA, Ige T (2010). Economics of Seed Yam Production using minisett technique in Oyo State, Nigeria Field Actions Sci. Reports. Online, Vol. 4 (URL: http:// factsreports.revues.org/659).

Ohiri AC, Ezumah HC (1990). Tillage effects on cassava (Manihotesculenta) production and some sol properties. Soil Tillage Res. 17: 211-229.

Ohiri AC, Nwokoye JU (1984). Soil physical and chemical properties suitable for yam (Dioscorea rotundata) production. Intl. Society of Tropical Root Crops. Pp. 21-26.

Okoli OO, Akoroda MO (1995). Providing seed tubers for the production of food yams. Afr. J.Root Tuber crops1 (1): 1-6.

Ondo Ovono P, Kevers C, Dommes J (2010). Effects of storage conditions on sprouting of micro tubers of yam (Dioscoreacayenensis-Dioscorearotundata complex). Comptes, 
042 Int. Res. J. Agric. Sci. Soil Sci.

Rendus Biologie. $233: 28-34$.

Ondo Ovono P, Kevers C, Dommes J (2015). Behavior of various types of seeds of two species of yams tuber (Dioscoreacayenensis Lam. and Dioscorearotundata Poir.) in Gabon. Int. Res. J. Agric. Sci. Soil Sci. 5 : 58-66.

Orkwor GC, Ekanayake IJ (1998). Growth and development. In :G.C.Orkwor, R.Asiedu and I.J. Ekanayake (Eds), Food yams : advances in research, NRCRI IITA Ibadan pp. 105-142.

Otoo JA, Osiru DSO, Ng SY, Hahn SK (1987).Improved Technology For Seed Yam Production.2nd Edition, IITA, Ibadan, Nigeria, 56.

Otoo E, Anyakanmi TG, Kikuno H, Asiedu R (2016). In Vivo Yam (Dioscorea spp.) Vine Multiplication Technique: The Plausible Solution to Seed Yam Generation Menace. J. Agric. Sc. 8, 88-97.

Park BJ, Onjo M, Tominaga S, Hayashi M (2001). The relationship between plant hormones and dormancy of tuber in yams (Dioscorea spp.) Jap. J. Trop. Agric. 44 : 29-30.

Passam HC (1977). Sprouting and apical dominance of yam tubers. Trop. Sc. 19: 29-39.

Riley CK, Adebayo SA, Wheatley AO, Asemota HN (2006). Fundamental and derived properties of yam (Dioscorea spp.) starch powders and implications in tablet and capsule formulation. Starch/Starke. 58: 418-424.

Rivera JR, Gonzales MA, Collazo de Rivera A, Cuevas-Ruiz I (1974). An improved method for storing yam (Dioscorea alata). J. Agric. of the Uni. Puerto Rico 58: 450-465.

Sheeba RI, Janova V, Remya N, Krishnan A (2013). Influence of Nursery Media and Mulching on Sprouting and Growth of Greater yam (Dioscorea alata) Minisetts. J. Root Crops. $39: 247-249$.

Shiwachi H, Ayankanmi T, Asiedu R, Onjo M (2003). Induction of germination in dormant yam (D. rotundata spp.) tubers with inhibitors of gibberellins. Exp. Agric. 39: 209- 217.

Shiwachi H, Kikuno H, Asiedu R (2005). Micro tuber production using yam (D. rotundata) vines: Trop. Sc. 45 (4),163-169.

Tschannen AB, Escher F, Stamp P (2005). Post-harvest treatment of seed tubers with gibberellic acid and field performance of yam (Dioscoreacayenensis-rotundata) in Ivory Coast. Expl. Agric. 41: 175- 186.

Vakis NJ (1986). Influence of physiological ageing of seed potatos on yield and ealiness. Potatos Res. 29: 417- 425

Wickham LD, Passam HC, Wilson LA (1984). Dormancy responses to post-harvest application of growth regulators in Dioscorea species, 2.Dormancy responses in ware tubers of D.alata and D. esculenta J. Agric. Sci. 102: 433-436.

Yuan S, Yan YC, Lin HH (2005). Plant regeneration through somatic embryogenesis from callus cultures of Dioscorea zingiberiensis. Plant Cell Tiss. Organ Cult. 80: 157-161. 